\title{
RADIOCARBD N
}

Published by

THE AMERICAN JOURNAL, OF SCIENCE.

Editors

EDWARD S. DREVEY - RICHARD FOSTER FLINT

J. GORDON OGDEN, III-IRVING ROLSE

Managing Editor

RENEE S. KRA 


\title{
R A D I O C A R B O N
}

Editors: Edward S. Deevey-Richard Foster Flint-J. Gordon Ogden, III-Irving Rouse Managing Editor: RENEE S. KRA

\author{
Published by
}

\section{THE AMERICAN JOURNAL OF SCIENGE \\ Editors: JOHN RODGERS AND JOHN H. OSTROM}

Published semi-annually, in Winter and Summer, at Yale University, New Haven, Connecticut.

Subscription rate $\$ 30.00$ (for institutions), $\$ 20.00$ (for individuals), available only by volume.

All correspondence and manuscripts should be addressed to the Managing Editor, RADIOCARBON, Box 2161, Yale Station, New Haven, Connecticut 06520.

\section{INSTRUCTIONS TO CONTRIBUTORS}

Manuscripts of radiocarbon papers should follow the recommendations in Suggestions to Authors, 5th ed.* All copy must be typewritten in double space (including the bibliography): manuscripts for vol. 12, no. 2 must be submitted in duplicate by January 1, 1970, and for vol. 13, no. 1 by September 1, 1970.

Description of samples, in date lists, should follow as closely as possible the style shown in this volume. Each separate entry (date or series) in a date list should be considered an abstract, prepared in such a way that descriptive material is distinguished from geologic or archaeologic interpretation, but description and interpretation must be both brief and informative. Date lists should therefore not be preceded by abstracts, but abstracts of the more usual form should accompany all papers (e.g. geochemical contributions) that are directed to specific problems.

Each description should include the following data, if possible in the order given:

1. Laboratory number, descriptive name (ordinarily that of the locality of collection), and the date expressed in years B.P. (before present, i.e. before A.D. 1950) and, for finite dates, in years A.D./B.c. The standard error following the date should express, within limits of $\pm 1 \sigma$, the laboratory's estimate of the accuracy of the radiocarbon measurement, as judged on physicochemical (not geologic or archaeologic) grounds.

2. Substance of which the sample is composed; if a plant or animal fossil, the scientific name if possible; otherwise the popular name; but not both. Also, where pertinent, the name of the person identifying the specimen.

3. Precise geographic location, including latitude-longitude coordinates.

4. Occurrence and stratigraphic position in precise terms.

5. Reference to relevant publications. Citations within a description should be to author and year, with specific pages wherever appropriate. References to published date lists should cite the journal, year, vol., and specific page (e.g., Radiocarbon, 1968, v. 10, p. 97). Full bibliographic references are listed alphabetically at the end of the manuscript, in the form recommended in Suggestions to Authors.

6. Date of collection and name of collector.

7. Name of person submitting the sample to the laboratory, and name and address of institution or organization with which submitter is affiliated.

8. Comment, usually comparing the date with other relevant dates, for each of which sample numbers and references must be quoted, as prescribed above. Interpretive material, summarizing the significance and implicity showing that the radiocarbon measurement was worth making, belongs here, as do technical matters, e.g. chemical pretreatment, special laboratory difficulties, etc.

Illustrations should not be included unless absolutely essential. They should be original drawings, although photographic reproductions of line drawings are sometimes acceptable, and should accompany the manuscript in any case, if the originals exceed 9 to 12 inches in size.

Reprints. Thirty copies of each article, without covers, will be furnished without cost. Additional copies and printed covers can be specially ordered.

Back issues. Back issues (vols. 1-9) are available at a reduced rate to subscribers at $\$ 50.00$ a set; vol. 10 and subsequent volumes are $\$ 20.00$ for individual subscribers and $\$ 30.00$ for institutions; single issues are $\$ 10.00$ each.

* Suggestions to authors of the reports of the United States Geological Survey, 5th ed., Washington, D. C., 1958 (Government Printing Office, \$1.75). 


\section{NOTICE TO READERS}

Half life of $\mathbf{C}^{14}$. In accordance with the decision of the Fifth Radiocarbon Dating Conference, Cambridge, 1962, all dates published in this volume (as in previous volumes) are based on the Libby value, $5570 \pm 30 \mathbf{~ y r}$, for the half life. This decision was reaffirmed at the $\mathrm{H}^{3}$ and $\mathrm{C}^{14}$ Conference, Pullman, Washington, 1965. Because of various uncertainties, when $\mathrm{C}^{14}$ measurements are expressed as dates in years B.P. the dates are arbitrary, and refinements that take some but not all uncertainties into account may be misleading. As stated in Professor Harry Godwin's letter to Nature (v. 195, no. 4845, p. 984, September 8, 1962), the mean of three new determinations of the half life, $5730 \pm 40$ $\mathrm{yr}$, is regarded as the best value now obtainable. Published dates can be converted to this basis by multiplying them by 1.03 .

A.D. B.C. dates. As agreed at the Cambridge Conference in 1962, A.D. 1950 is accepted as the standard year of reference for all dates, whether B.P. or in the A.D./B.C. system.

Meaning of $\delta \mathbf{C}^{14}$. In Volume 3, 1961, we indorsed the notation $\Delta$ (Lamont VIII, 1961) for geochemically interesting measurements of $\mathrm{C}^{14}$ activity, corrected for isotopic fractionation in samples and in the NBS oxalic-acid standard. The value of $\delta \mathrm{C}^{14}$ that entered the calculation of $\Delta$ was defined by reference to Lamont VI, 1959, and was corrected for age. This fact has been lost sight of, by the editors as well as by authors, and recent papers have used $\delta \mathrm{C}^{14}$ as the observed deviation from the standard. This is of course the more logical and self-explanatory meaning, and cannot be abandoned now without confusion; moreover, except in tree-ring-dated material, it is rarely possible to make an age correction that is independent of the $\mathrm{C}^{14}$ age. In the rare instances where $\Delta$ or $\delta \mathrm{C}^{14}$ are used for samples whose age is both appreciable and known, we assume that authors will take special care to make their meaning clear; reference merely to " $\Delta$ as defined by Broecker and Olson (Lamont VIII)" is not adequate.

Radiocarbon Measurements: Comprehensive Index, 1950-1965. This index, covering all published $\mathrm{C}^{14}$ measurements through Volume 7 of RADIOCARBON, and incorporating revisions made by all laboratories, has been published. It is available to all subscribers to RADIOCARBON at ten dollars U.S. per copy.

Publication schedule. Volume 10 and subsequent volumes are published in two semi-annual issues, in Winter and in Summer, with deadlines for manuscripts on 1 September and 1 January. Because of the recent rise in the number of manuscripts and laboratories, our publication schedule may be slightly delayed in the future. Contributors who meet our deadlines will be given priority but not guaranteed publication in the following issue.

List of laboratories. The comprehensive list of laboratories that has appeared hitherto at the end of each issue will now appear only once a year, in the second number of each volume.

Index. Beginning with Volume 11, all dated samples now appear in index form at the end of the second number of each volume. 


\section{RA D I O C A R B O N}

Published by

THE AMERICAN JOURNAL OF SCIENCE

Editors

EDWARD S. DEEVEY - RICHARD FOSTER FLINT

J. GORDON OGDEN, III -IRVING ROUSE

Managing Editor

RENEE S. KRA

YALE UNIVERSITY

NEW HAVEN, CONNECTICUT 


\section{CONTENTS}

\begin{tabular}{|c|c|}
\hline NU & $\begin{array}{l}\text { H. A. Polach, J. F. Lovering, and J. M. Bowler } \\
\text { Australian National University Radiocarbon Date List IV ..... }\end{array}$ \\
\hline BONN & $\begin{array}{l}\text { H. W. Scharpenseel and F. Pietig } \\
\text { University of Bonn Natural Radiocarbon Measurements III }\end{array}$ \\
\hline $\mathrm{Fr}$ & $\begin{array}{l}\text { Wolfgang Burkhardt, Hajo Stechemesser, and Dietrich Mania } \\
\text { Freiberg Radiocarbon Measurements I }\end{array}$ \\
\hline GSC & $\begin{array}{l}\text { Weston Blake, Jr. and J. A. Lowdon } \\
\text { Geological Survey of Canada Radiocarbon Dates IX }\end{array}$ \\
\hline I & $\begin{array}{l}\text { James D. Buckley and Eric H. Willis } \\
\text { Isotopes' Radiocarbon Measurements VIII }\end{array}$ \\
\hline LE & $\begin{array}{l}\text { P. M. Dolukhanov } \\
\text { Khlopin Institute Radiocarbon Dates II }\end{array}$ \\
\hline $\mathrm{Lv}$ & $\begin{array}{l}\text { E. Gilot } \\
\text { Louvain Natural Radiocarbon Measurements VIII }\end{array}$ \\
\hline M & $\begin{array}{l}\text { H. R. Crane and James B. Griffin } \\
\text { University of Michigan Radiocarbon Dates XIII }\end{array}$ \\
\hline NPL & $\begin{array}{l}\text { W. J. Callow and Geraldine I. Hassall } \\
\text { National Physical Laboratory Radiocarbon Measurements VII }\end{array}$ \\
\hline NTU & $\begin{array}{l}\text { Yuin-chi, Chia-yi huang, and Shih-chong Lu } \\
\text { National Taiwan University Radiocarbon Measurements I }\end{array}$ \\
\hline SI & $\begin{array}{l}\text { Robert Stuckenrath, Jr. and James E. Mielke } \\
\text { Smithsonian Institution Radiocarbon Measurements VI }\end{array}$ \\
\hline$T$ & $\begin{array}{l}\text { Reider Nydal, Knut Lovseth, and Oddveig Syrstad } \\
\quad \text { Trondheim Natural Radiocarbon Measurements V }\end{array}$ \\
\hline TA & $\begin{array}{l}\text { E. Ilves, J. M. Punning, and A. Liiva } \\
\text { Tartu Radiocarbon Dates IV }\end{array}$ \\
\hline$T x$ & $\begin{array}{l}\text { S. Valastro, Jr. and E. Mott Davis } \\
\text { University of Texas at Austin Radiocarbon Dates VII }\end{array}$ \\
\hline $\mathbf{U}$ & $\begin{array}{l}\text { Ingrid U. Olsson and Martin Klasson } \\
\text { Uppsala Radiocarbon Measurements X. }\end{array}$ \\
\hline UB & $\begin{array}{l}\text { A. G. Smith, G. W. Pearson, and J. R. Pilcher } \\
\text { University of Belfast Radiocarbon Dates I }\end{array}$ \\
\hline UB & $\begin{array}{l}\text { A. G. Smith, G. W. Pearson, and J. R. Pilcher } \\
\text { University of Belfast Radiocarbon Dates II }\end{array}$ \\
\hline VRI & $\begin{array}{l}\text { Heinz Felber } \\
\quad \text { Vienna Radium Institute Radiocarbon Dates I }\end{array}$ \\
\hline W & $\begin{array}{l}\text { B. M. Sullivan, E. Spiker, and M. Rubin } \\
\text { U. S. Geological Survey Radiocarbon Dates XI }\end{array}$ \\
\hline WIS & $\begin{array}{c}\text { Margaret } M . \text { Bender, Reid A. Bryson, and David A. Bae } \\
\text { University of Wisconsin Radiocarbon Dates VII }\end{array}$ \\
\hline
\end{tabular}

